\title{
Changing Security Regime in the Baltic Sea Region*
}

\begin{abstract}
Though the Baltic Sea region appears to be an ideal place for the formation of classical regional security regime, this assumption appears to be substantially wrong for one simple reason - Russia cannot accommodate itself in this regional format. Therefore, only international institutions of a wider scope are capable of resolving the dilemma of Baltic security and performing the conflict prevention function. CSCE successfully coped with this task in 1991-1994. CSCE was the international format that ensured successful withdrawal of Russian troops from the Baltic States. However it soon became clear that the organisation is of little use in further settlement and normalisation of the Baltic-Russian relations. Therefore, the regional Cold War could only be ended by the influence of international institutions capable of conducting equal dialogue with Russia. And NATO could became such institution. After uniting its former antagonists into NACC, then into EAPC and PfP, and after 2002 decision to invite the Baltic States to start accession talks, it managed to find a peculiar form of institutionalisation of relations with Russia. Therefore one may say that the security regime in the Baltic Sea region is becoming a NATO-centric regime because even countries formally not members of NATO will have established solid relations with this organisation. This applies to Finland and Sweden for a long time already. And there is a chance now that the same will soon apply to Russia.
\end{abstract}

\section{Introduction}

Despite many important changes in the Baltic Sea region and renewing dynamism of the security system, it is universally recognised that the region was and remains one of the most stable places in Europe. As bloody conflicts raged in the former Yugoslavia in the last decade, reporters more than once compared the Baltic region with the Balkans in order to stress that, despite the similarity of sounding of the names, the troublesome Balkans could learn much from the stable Baltic area. It seems that today we already have a quite exhaustive answer to the question as to why the Balkans are so unstable. The problem has been analysed very thoroughly, while the question about the Baltic region's stability has received much less attention. This is understandable - stability is not a thing that hits the headlines frequently. However, at a closer look, one sees that the phenomenon of regional stability is perhaps not less

"Prof., dr. Gediminas Vitkus - Head of the Political Science Department of the Lithuanian Military Academy, Associate Professor of Institute of International Relations and Political Science of the University of Vilnius. Address: Šilo 5a, LT-2055 Vilnius, Lithuania tel. +370-5-2127970, e-mail: gediminas.vitkus@tspmi.vu.lt

The author is grateful to the NATO-EAPC Research Fellowship Program for support. 
interesting that the problem of regional conflicts. The fact that grandiose changes that took place in the Baltic Sea region over the last decade of the $20^{\text {th }}$ century did no impact upon its stability and the existing conflict pressures had not transformed into open conflicts and use of force, forms a sufficient basis for raising a question what supports such stability and what are the mechanisms of its reproduction and prospects of its further development.

Answers to these questions should be first of all sought in analytical literature devoted to the problems of the Baltic Sea region security. It should be noted that, generally, these problems receive really much attention on the part of researchers. Over the last decade a multitude of articles and books on this subject have been published; it is difficult to count conferences and workshops devoted to it. The Baltic region studies have been developed intensively both in the Baltic States themselves and in the research centres of other countries. A visitor to the web sites of the most famous research centres and universities will undoubtedly find literature on the subject of the Baltic Sea region security ${ }^{1}$. Voices of researchers from the smallest of the Baltic Sea States are heard more and more frequently ${ }^{2}$. As quite many countries are situated around the Baltic Sea, it has become a tradition to hold international conferences or launch international projects and publish collective monographs in which official or unofficial expert opinions from all countries of the region on various regional security aspects are presented ${ }^{3}$. Admittedly, the number of monographs by individual authors is smaller. The number of authors is proportional to the number of countries covered by the monographs. Usually they are devoted to the Nordic or the Baltic States rather than to the Baltic Sea region as a whole ${ }^{4}$.

Thus literature is really abundant and one just cannot encompass all the sources available. The abundance of publications on the Baltic security issue not only testifies to comprehensiveness and exhaustiveness of its study but also leaves little space for innovations. After the familiarisation with the literature, one gets an im-

\footnotetext{
${ }^{1}$ See useful links: http://www.usemb.se/BalticSec/links.html; http://www.csm.org.pl/en_index.html ${ }^{2}$ Probably the Latvian Institute of International Affairs holds the leadering position among Baltic research institutions (http://www.lai.lv). Also see useful links: http://www.evi.ee/english/link.html. ${ }^{3}$ See for example: Wellmann C., ed., The Baltic Sea Region: Conflict or Cooperation? Region Making, Security, Disarmament and Conversion. Proceedings of the TAPRI-PFK-Workshop, Kiel, December 6-8,1991, Munster, Hamburg: Lit Verlag, 1992; Joenniemi P \& Vares P., eds., New Actors on the International Arena: The Foreign Policies of the Baltic Countries, Tampere: TAPRI, 1993 (Research Report, No. 50); Petersen N., eds., The Baltic States in International Politics, Copenhagen: DJØF Publishing, 1993; Arteus G., Lejins A., eds., Baltic Security. Looking towards the 21st century, Riga and Stockholm, 1997; Mouritzen H., ed., Bordering Russia: Theory and Prospects for Europe's Baltic Rim, Ashgate, 1998; Rotfeld A.D. ed., The New Security Dimensions. Europe After the NATO and EU Enlargements. Report of the Frosunda Conference, Frosunda, April 20-21, 2001, Stockholm: SIPRI, 2001; etc.

${ }^{4}$ The following publications are nevertheless worth mentioning: Hidden J., Salmon P., The Baltic Nations and Europe. Estonia, Latvia and Lithuania in the Twentieth Century, revised edition, London and New York: Longman, 1995.; Knudsen O.F., "Cooperative security in the Baltic Sea region", Chaillot Paper 33, Paris: Institute for Security Studies of WEU, 1998. Web edition - http:/ /www.iss-eu.org/chaillot/chai33e.html, accessed June 1, 2002; Perry Ch. M., Sweeney M.J., Winner A.C., Strategic Dynamics in the Nordic-Baltic Region. Implications for US Policy, Brassaey's, 2000; Vaahtorana T., Forsberg T., "Post-Neutral or Pre-Allied. Finnish and Swedish Security Policies on the EU and NATO as Security Organizations", Working Paper of the Finnish Institute of International Affairs, Helsinki, 2000, no. 29; Clemens W. C. Jr., The Baltic Transformed: Complexity Theory and European Security, Lanham: Rowman \& Littlefields Publishers, 2001.
} 
pression that it would be difficult or practically impossible to say something new about these problems. Various aspects ranging from "hard" security to "soft" security, from foreign policy of individual states to the strategic balance and dynamics of the region have been examined. Therefore, the efforts of a researcher studying the Baltic Sea region security problems could be compared to an attempt to discover an unknown island in the Baltic Sea.

It is obvious that today one cannot expect to discover such island in the Baltic Sea, but nevertheless white spots can always be found in the system of knowledge built by us. And, as regards the above-mentioned issue - how the Baltic region's exceptional stability could be explained - such studies are not so numerous. Among the latest publications, mention should be made of an article by Rikard Bengtson ${ }^{5}$, in which the author seeks to find an answer to the question as to which conditions of a stable regional peace are already in place and which are still lacking. Though the definition of a stable peace is quite complicated, the conclusion drawn by the author is simple: "the analysis shows that the extensive web of cooperative schemes in place

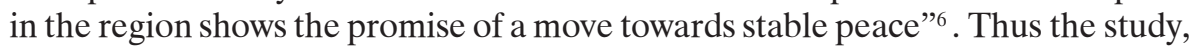
though identifying current trends, is focussed on future prospects.

Future is the main concern of perhaps the largest study on the Baltic Sea region that has appeared in recent years: a collective monograph edited by Olaf F. Knudsen, entitled "Stability and Security in the Baltic Sea Region" . The collective nature of the monograph means that the range of the aspects covered is very wide, while the analysis of the problem is based on various theoretical approaches. However, despite the common title of the book the very phenomenon of the Baltic Sea region stability has not become a subject of direct study. It is interesting to note that, though at the beginning the authors usually do not deny that the region is stable enough, in the course of analysis attention becomes focussed on the ways to strengthen stability further. In other words, an assumption is as if programmed at the subconscious level of the authors' minds that the region is actually not so stable as it seems, and that real stability still needs to be achieved. Therefore, this book, just as a number of other publications, pursues a "normative" objective: to provide guidelines on what should be done further. So it is not surprising that these studies do not give a more exhaustive explanation of the stability phenomenon itself. It is namely this gap in the analytical literature that the present work intends to fill.

The main assumption or working hypothesis underlying this project, which should assist in searching for an answer, is the idea that there exists something behind the individual foreign policy actors in the Baltic Sea region that maintains stability, because no power in the region is seeking to satisfy its interests to a full extent. And that "something" is nothing but adherence to certain standards of behaviour, which are probably generated by certain international institutions. In this case, the motives inducing the states of the region to act in a specific way are not of primary importance. The most important thing is the fact that the existence of certain norms and rules can be observed in practice. In this context, it is worthwhile to remember Stephen Krasner's definition of international regimes (1988), which has already become classical:

\footnotetext{
${ }^{5}$ Bengtson R., "Towards a Stable Peace in the Baltic Sea Region?", Cooperation and Conflict, 2000 , vol. 35 (4), pp. 355-388.

${ }^{6}$ Ibid., p. 355.

${ }^{7}$ Knudsen O.F., ed., Stability and Security in the Baltic Sea Region, London: Franc Cass, 1999.
} 
international regimes are defined as principles, norms, rules, and decision-making procedures around which actor expectations converge in a given issue-area"

If we agree with the assumption that, in the Baltic Sea region, security issues are mostly regulated by norms, rules of behaviour or conventions acceptable to all local actors, then we have a sufficiently strong basis for the formulation of a hypothesis that a definite security regime has been manifesting itself (has formed or is forming) in the region over the last decade, and it is namely this regime that generates stability observed in the region.

The application of this definition of the security regime to specific regions may be a bit doubtful. This is really problematic because, as shown by analysis of relevant literature, it is virtually impossible to provide an unquestionable definition of a region. But in this case we have not relied upon a strict geographical definition of the Baltic Sea region. The focus of attention embraced not only the Baltic States but also all other actors that for some reason were, in one way or another, involved in or related to the control and regulation of the central conflict line, i.e. the dilemma of the security of the Baltic States and Russia. Therefore, in principle, an international security regime functioning in a region must not necessarily be regional itself. In this case one should speak about the specificity of the regional operation of a regime with wider coverage.

Thus the main objective of this research project is to try to characterise the security regime forming in the Baltic Sea region including the transformations of its principles and norms over the last decade, from the end of the Cold War up to the present, when the Baltic States are on the threshold of the NATO membership, and a new shape of co-existence of the West and Russia is emerging.

The very concept of "the security regime" helps define the basic methodological approach of the study - neoliberal institutionalism. This theoretical approach ${ }^{9}$ formed in the 1980s as a reaction to the neorealist theory of international relations elaborated in Kenneth Waltz' book "Theory of International Politics"10 in 1979. Neoliberal institutionalism agrees with neorealism that states and balance of power play a central role in international politics. However, at the same time this school notes that, while placing emphasis on the competitive nature of international politics, neorealism underestimates the fact that states not only compete but also cooperate and even create certain international norms, rules and institutions, which, in turn, start influencing policies of these states. Therefore, according to the theorists of neoliberal institutionalism, in order to grasp international political processes, one must analyse both the states' power balance and the existing international institutions with their inherent norms and conventions of international behaviour. Numerous international institutions and organisations of various types are established for the purpose of uniting the states' efforts in attaining certain aims or of simply facilitating

\footnotetext{
${ }^{8}$ Krasner, S.D., "Structural causes and regime consequences: regimes as intervening variables" in Krasner, S.D. ed., International Regimes, Ithaca and London: Cornell University Press, 1988, p. 2. ${ }^{9}$ See for instance: Axelrod, R., Evolution of Cooperation, New York: Basic Books, 1984; Oye, K., ed., Cooperation Under Anarchy: Princeton: Princeton University Press, 1986; Keohane, R.O., International Institutions and State Power: Essays in International Relations Theory, Boulder, CO: Westview, 1989.

${ }^{10}$ Waltz, K. N., Theory of International Politics, Reading (Mass.) etc.: Addison-Wesley Publishing Company, 1979.
} 
interstate cooperation; however, according to the representatives of this school, in certain circumstances, international institutions may even play a decisive role in resolving or regulating problems of international politics.

Finally, one must note that, along with the principal neoliberal institutionalist approach, the study also employs historical analysis, by means of which the author attempts to identify the stages and specificity of the changes that have taken place in the area of the Baltic Sea region security as well as to describe the evolution of the main institutions engaged in security issues, first of all CSCE and NATO. The main stages which suggested the structure of the paper had been identified according to substantial changes in the constellation of regional security. The first stage covers a period from the end of the Cold War till the end of 1994, when the legacy of the Cold War was intensively eliminated in both the Baltic Sea region and Eastern Europe as a whole. The second stage, from 1995 till 2001, is substantially a period when the main actors of the region still could not make final decisions and considered several alternatives for the future security regime in the Baltic Sea region. The year 2001 may be regarded as a kind of threshold when a NATO-centric security regime supported by two main pillars - the balanced groups of NATO states and NATO partners - was finally established in the region.

\section{1990 - 1994: The Takedown of the Nordic Balance}

During the Cold War, the confrontation between the superpowers and their allies was diluted by certain specificity in the Baltic Sea region. A rather peculiar model of security regime had formed in this region, called the Nordic Balance by analysts. This meant that the confrontation in the Baltic Sea region was not direct as in Germany; the areas under the influence of the superpowers and their allies were delimited by neutral buffer states, Sweden and Finland. Even the neutrality of these two states had different features. Though formally neutral, Sweden was, nevertheless, connected with NATO by numerous informal security ties ${ }^{11}$. Meanwhile, Finland was forced to sign an unfavourable Friendship, Cooperation and Mutual Assistance Agreement (FCMA) with the Soviet Union in 1948. Under this agreement, Finland practically lost the opportunity for pursuing an independent national security policy, even though the Soviets, in exchange for this restriction, did not interfere with Finland's internal affairs, and the country could independently develop economic and cultural ties with European states. Thus unwritten security norms and rules in this region were slightly different from those of Eastern Europe, and though nobody was very much satisfied with them, there were neither intentions nor possibilities for changing them substantially.

The dynamic process of changes in the Baltic Sea region after the Cold War and the end of global confrontation transformed the main lines of potential interstate conflicts in the region. The main point of conflicts and the source of security dynamics shifted to the sphere of relations of the restored Baltic States - Lithuania, Latvia and Estonia - with Russia. But for the huge difference in the power of the small Baltic

${ }^{11}$ For details see: Vaahtorana T., Forsberg T., "Post-Neutral or Pre-Allied? Finnish and Swedish Security Policies on the EU and NATO as Security Organizations", Working Papers of the Finnish Institute of International Affairs, Helsinki, 2000, no. 29. pp. 7-9 
Republics and Russia and the peculiar geopolitical position of the Baltic States denying Russia's access to the Baltic Sea, the significance of this conflict line would not be so great. The security of the Baltic States poses a problem first of all because the Baltic region will always remain the one of strategic importance to Russia. In spite of the fact that Russia's interests are much wider and cannot be concentrated upon a single region, Russia does not wish and cannot withdraw for many reasons. Therefore, the Russian-Baltic relations have created and should continue to create a pressure in the region first of all due to significant differences in these states' attitudes towards the security problem. Other countries of the region and international institutions unavoidably had to react to these pressures. All this constituted a conflict axis around which the new security regime of the Baltic Sea region started to form.

\subsection{Main Changes in the Baltic Sea Region after the Cold War}

Changes in the Baltic Sea region started a bit later than in Eastern Europe. If by the end of 1989 almost all Central European states had liberated themselves from the communist rule and restored their sovereignty, in the Baltic region, the forthcoming changes were foretold by national liberation movements in the three republics - Estonia, Latvia and Lithuania - still controlled by the Soviet Union. But Moscow did not intend to abandon control over them in spite of fundamental changes in its posture on the international arena. Even the issue of Finland, whose sovereignty was restricted by the FCMA agreement of 1948, was not discussed publicly at that time, though the uniting of Germany, accomplished in 1990, meant that, substantially, any restrictions on sovereignty of Germany and its former allies should be finally removed. Therefore, the most important change that provided an impetus for fundamental developments in the Baltic Sea region was not Gorbachev's policy aimed at ending the confrontation with the USA and its allies, but the collapse of the Soviet Union at the end of 1991. The disappearance of this empire from the political map made both a substantial change in the geopolitical situation and opened entirely new opportunities never considered earlier.

It was due to this substantial change that the Baltic Sea region changed beyond recognition during 1991-1994. All the states of the region, just as other Central and Eastern European countries, regained freedom and sovereignty and could establish such mutual relations as they deemed necessary. Therefore, much depended on the choice of orientation and security policy by the governments of the states no longer restricted by external limitations. For example, in 1991, Sweden, one of the region's most important states, decided to join the European Community and submitted an application to the European Commission; in May 1992, the Swedish Parliament revoked neutrality, the Swedish foreign policy principle of long standing, and announced that Sweden would remain neutral only in case of war. This opened an opportunity for Sweden to cooperate with other states and organisations in peacetime and to seek membership of the European Community.

Important developments also took place in the security policy of Poland another Eastern European state important for the Baltic region. During the Cold War, this country found itself in a quite ambiguous situation in terms of security. Its sovereignty was considerably restricted by both the power of the Soviet Union and security guarantees provided by the latter. Western territories acquired by Poland 
after World War II were a kind of compensation for the lost eastern lands, which today form part of the Ukraine, Belarus and Lithuania. However, together with the "regained" western lands Poland received a threat that, in case of a change in the international situation and uniting of Germany, part of its territory may once again become an object of claims on the part of Germany. Therefore, it is very important for the stability of the region that Poland would regulate its relations with its neighbours Germany, the Ukraine, Belarus and Lithuania - without any intermediaries. Poland managed to achieve this by 1994.

The main thing, however, that the Baltic Sea region states wished to secure after the collapse of the Soviet Union was, undoubtedly, final and irrevocable dismantling of the relics testifying to the former Soviet predominance on the eastern Baltic seacoast: the above-mentioned FCMA in case of Finland and the withdrawal of Russian troops in case of Estonia, Latvia and Lithuania.

The initial term of the validity of FCMA treaty concluded by Finland and the Soviet Union in 1948 was ten years, but in 1955, it was re-written so as to extend the term up to twenty years. The term was extended again in 1970 and 1983. Even in March 1991, the $43^{\text {rd }}$ anniversary of the agreement was marked as usual. Thus it seemed that, despite substantial changes in Europe, the Soviet Union tended to change nothing and maintain the Nordic balance regime in the Baltic Sea region which was advantageous to it. However, the failure of the communist putsch in August 1991 revealed that the Soviet Union was no longer in a position to stop changes in the Baltic Sea region.

The key interest of Finland in these negotiations was, undoubtedly, a wish to eliminate any hint to the spirit of the previous FCMA; it strove that even no mention of it would be made in the text of the new agreement. According to the Finnish negotiator Jaakko Blomberg:

All in all, the difficult heritage of the FCMA treaty was buried without a notable discord, and the new treaty included no special bilateral security policy obligations that go beyond those already binding all European States on the basis of agreed-upon general conventions ${ }^{12}$.

Thus multilateral international agreements (such as the UN Charter, the Final Act of the European Conference for Security and Cooperation in Helsinki and the Paris Charter) outlining the states' standards of behaviour rather than a complicated history of Finnish-Russian relations formed a framework for a new treaty. In other words, Finland sought to place new relations with Russia into a wider international context and to finally stop the sad practice of the past "special" relations.

The collapse of the Soviet Union and the emergence of independent Baltic States was probably one of the principal incitements that changed the entire geostrategic situation in the Baltic Sea region. While the Soviet Union was a dominating power in the Baltic Sea region, the Russian Federation as its heir received only insignificant areas on the Baltic seacoast: the Kaliningrad exclave and St. Petersburg region. However, such change in the situation gave rise to a new line of conflict

${ }^{12}$ Quoted in Pursiainen C., "Finland's Policy Towards Russia. How to Deal With the Security Dilemma?", Northern Dimensions 2000. Yearbook of the Finish Institute of International Affairs, Helsinki, 2000, p. 70. 
between the Baltic States and Russia, with the ensuing threat to the regional security. A possibility of direct Russian intervention was not the main cause of the pressure. The new Russian state and its political leaders could not question the Baltic States' independence itself - at least with regard to the earlier development of mutual relations when Russian politicians attempted to use the Baltic States in their competition with the Soviet Union's leaders. However, as the Soviet Union disintegrated and was replaced by Russia, both the legal form and content of bilateral Baltic-Russian relations had to change inevitably. Though nobody disputed the independence of the Baltic States, the choice of the status quo of their relations with Russia was rather wide as of the end of 1991. The Baltic States still accommodated the armed forces controlled by Russia; the economy of the new states was fully integrated in the economic space of the former Soviet Union; many Russians - immigrants from the Soviet Union - lived in the Baltic States, who suddenly found themselves living abroad as the Soviet Union collapsed. Therefore, it is quite natural that in this period the Baltic States and Russia faced many unresolved issues related to the dismantling of the Soviet Union's legacy.

From the standpoint of the regional security, the main problems for the Baltic States, just as for the entire Central and Eastern Europe, included the withdrawal of the army controlled by Russia and the legalisation of state borders, former administrative boundaries of the Soviet republics. Soon it turned out that reaching an agreement on these issues with Russia was quite difficult for the Baltic States. Russia's unwillingness to agree was determined by both objective and subjective reasons. Russia had to meet the obligations of the army withdrawal from East Germany and Poland. Furthermore, the withdrawn troops had to be accommodated in new places of deployment, which were overfilled or not yet fitted out. Russia inherited a huge army from the Soviet Union, which held the entire democratic world in pressure but which was clearly excessive for the purposes of Russia's defence. For this reason the Russian government was interested in delaying the withdrawal, at least from the Baltic States, as long as possible. Therefore, no date of the withdrawal was mentioned at the beginning of the negotiations; later, 1997-1999 started to be mentioned as the deadline for the withdrawa ${ }^{13}$.

Thus the only way for a speedy resolution of the problem of the foreign army's withdrawal that the political leaders of the Baltic States could choose was immediate internationalisation of the problem, making it a problem of the entire international community. In this situation the Baltic States had considerable opportunities as members of the principal international organisations, the UN and CSCE.

Strict internationalisation of the problem of the Russian troops' withdrawal was a tactics that brought both success and certain costs to the Baltic States. Their relations with Russia worsened to such an extent that they could even be called a

\footnotetext{
${ }^{13}$ The first negotiations between Russia and all three Baltic States on the issue of troop withdrawals took place on January 31 - February 2, 1992. The talks with Lithuania and Latvia concluded with an agreement that troops would begin to leave the Baltic States in February. But no indication of a date for the completion of troop withdrawals was given. The talks between the Russian Federation and separate delegations from all three States appeared to be making little progress. In May 4-7. 1992, the Russian First Deputy Foreign Minister Fyodor Shelov-Kovedyayev accompanied by a delegation including Col.-Gen. Valery Mironov, Commander of the North-western Group of Forces toured Estonia, Latvia and Lithuania. In response to Baltic demands for an immediate troop withdrawal, the Russian side repeated that the withdrawal of former Soviet forces from the Baltic States before 1997-99 would depend on the material provision for the servicemen.
} 
regional "Cold War". The reason for the conflict was the legal status of the Russianspeaking population in Latvia and Estonia. Of the three Baltic States, Latvia and Estonia had proportionally bigger Russian-speaking minority ${ }^{14}$. Therefore, while there was no discrimination of Russian-speaking population under the Lithuanian Law on Citizenship and these persons could receive Lithuanian citizenship without any obstacles, the situation in Latvia and Estonia was completely different.

During the summer of 1992 Russian officials began to link the withdrawal of troops from Estonia and Latvia to the issue of the Russian minority rights. In addition, Russia was now in a position to link the withdrawal not only to the situation of the Russian-speaking population in the Baltic States but also to strive for internationalisation of this issue in response to the Baltic States' attempts to make the troop withdrawal problem international. Already in 1992 Russia applied to the Council of Europe and CSCEdrawing these organisations' attention to the human rights' situation in the Baltic States.

Russia's Cold War with Latvia and Estonia, which started in 1992, impeded the conclusion of troop withdrawal agreements; therefore, Russia conducted the withdrawal from these states on its own discretion. It was only on 30 April 1994 that the Presidents of Latvia and Russia signed an agreement under which the 10,000 Russian troops remaining in Latvia were to withdraw. A handful of Russian servicemen 500-600 personnel, were to remain to operate the Skrunda radar station on the Baltic coast until its closure some years later. In July, at the talks with President Meri in Moscow, Yeltsin agreed to withdraw the remaining 2,000 Russian troops from Estonia. Under a separate agreement signed in July, some 200 Russian specialists were to remain at the Russian submarine base in Paldiski, which had to be dismantled under civilian supervision, by September 1995. The last Russian units officially left Estonia and Latvia on 29 August 1994.

\subsection{Stabilizing influence of international institutions in 1991-1994}

As one could have noticed, with important geopolitical changes in the region under way and new foundations for the relations in the area formed, the influence of international institutions that were active in the region, CSCE in particular, was very important if not crucial. In case of Finland there was no direct involvement of CSCE but the provisions of CSCE, documents laid a basis for a new interstate relations agreement with Russia. Meanwhile, the role of CSCE in resolving dilemmas concerning the Baltic-Russian relations and in maintaining regional stability was crucial in most cases. Without any doubt, the influence of CSCE induced Russia to change its position on the withdrawal of its army from the Baltic States and to decide on the completion of this process in 1994, along with the withdrawal of the remaining troops from Germany and Poland.

The stabilising role of CSCE and the Council of Europe also manifested itself in managing the rising conflict between Russia and Latvia/Estonia over the position of the Russian-speaking population. Through the internationalisation of the issue, Russia expected that international institutions would make Latvia and Estonia grant

${ }^{14}$ According to the latest census figures, ethnic Russians formed 8,7 percent of the Lithuanian population, as against the 30.4 per cent in Latvia and 28.1 per cent in Estonia. 
citizenship to all present residents; however, as it turned out later, the international community, though tending to mediate in settling the situation, nevertheless rejected the idea of linking the issue of national minorities with that of the withdrawal of troops. Numerous delegations of foreign inspectors and observer missions did not find any serious violations of human rights in the Estonian and Latvian laws on citizenship and naturalisation. Therefore, one even has grounds for asserting that it was owing to the influence of international institutions that "Russia's internationalization of ethnic issues in Estonia and Latvia created a situation that, in terms of balance, worked in favour of the Baltic States"15.

Thus, in the period from 1991 to 1994, CSCE played an undoubtedly central role in the Baltic Sea region as regards the establishment of rules and norms of the States' behaviour in the area of security relations. Other international institutions active in Europe and relevant to the Baltic Sea region's security - NATO and the European Community - were focused on internal restructurisation processes and did not undertake a more active role in the security issues of the region. In 1992, the EC member states that wished to deepen integration and to enrich it with a political and economic/monetary union encountered a crisis of the ratification of the Maastricht Treaty; the crisis was overcome only in 1993. Therefore, an attempt of the Baltic States to raise the problem of the withdrawal of Russian troops at the Council of the Baltic Sea States (initiated by Denmark and Germany, members of EC), failed ${ }^{16}$.

NATO, which was experiencing the time of changes, adaptation to new conditions and establishment of a new dialogue with former antagonists through NACC, also did not demonstrate any activity or wish to participate in the Baltic Sea region's security issues. Nonetheless NATO did not withdraw from the security problems of the region and made it clear that it intended to exert "a stabilising influence" there. On 11-16 March 1992, the Secretary General of NATO, Manfred Wörner visited Poland, Lithuania, Latvia and Estonia. Through his tour he repeated NATO's pledge that no "security vacuum" would be allowed to develop in Eastern Europe. He insisted that all countries of the region would benefit from NATO's stabilizing influence, but warned that the alliance would not be able to offer formal security guarantees or membership.

However, though CSCE demonstrated that it was an organisation capable of regulating security issues and implementing conflict prevention under "peaceful" conditions, it appeared that the organization was helpless in case of crisis when one

\footnotetext{
${ }^{15}$ See: Norkus R., "Preventing Conflict in the Baltic States: A Success Story That Will Hold?" in Bonvicini G, et al., eds., Preventing Violent Conflict. Issues from the Baltic and Caucasus, BadenBaden: Nomos, 1998, p.153.

${ }^{16}$ On March 5-6 1992, foreign ministers of all 10 Baltic littoral states met in Copenhagen, Denmark, and agreed to establish a Council of the Baltic Sea States. The German-Danish initiative brought together Denmark, Estonia, Finland, Germany, Latvia, Lithuania, Norway, Poland, Russia and Sweden. Its aim was to create a community in which assistance could be given to Russia, Poland and the three former Soviet Baltic States to transform themselves into free-market societies. However, the Danish Foreign Minister and co-chairman of the meeting Uffe Ellemann-Jensen emphasized that the Council would be closely linked to existing European organizations. $\mathrm{He}$ foresaw the Baltic region as a "region within the European Community" and said that regional cooperation would "facilitate the linkages of the European Community with the non-member countries of the region”. On March 6, Estonia, Latvia and Lithuania attempted to raise the issue of the delay in the withdrawal of former Soviet troops from their territory. However, Ellemann-Jensen stressed that the work of the Council would not duplicate that of existing international organizations and that security matters fell outside the scope of the new body.
} 
had to act very quickly or even apply force to control the conflicting sides. The CSCE's attempts to manage the process of Yugoslavia's disintegration failed: the resolution of conflict prevention problems in Moldova, the Caucasus and Transcaucasus was very difficult.

Therefore, its is quite natural that Central and Eastern European states, having restored their sovereignty successfully, nevertheless experienced a certain deficit of security and tended to look for more solid security guarantees than those offered by CSCE. As early as 1992, there appeared signs showing that the former Warsaw Pact members from Central Europe intended to seek active membership of NATO, seeing this as the fundamental aim of their policy of "returning to democratic Europe". Thus, at the end of 1993, the issue of NATO's eventual enlargement to Eastern Europe and explicit opposition of Russia became, perhaps, the most often discussed issue on the political agenda. In October, the pressure was further increased by an armed conflict between the President and the supporters of the revolted Parliament in Moscow. Finally, unexpected results of the election to Russian Parliament, where the Liberal-Democratic Party headed by the Russian ultranationalist Vladimir Zhirinovsky and communists received a majority, prompted the leaders of the three Baltic States to declare, at a meeting in Tallinn on 13 December, that their countries ask NATO to help ensure their security. Taking account of the situation, NATO countries had to decide on this urgent issue and give an answer, both to the countries wishing to join the organisation and to Russia.

However, this time a decision was adopted that NATO enlargement should be advanced slowly in the form of natural evolution, starting limited-scope defence agreements with individual Central and East European countries ${ }^{17}$. As it is known, the NATO summit meeting in January 1994 approved this plan, entitling it "Partnership for Peace (PfP)"

The PfP became a very important instrument of the stabilisation of the security situation in Eastern Europe, and its importance was increasing. Though in 1994, it was decided, to launch a CSCE reform and to reorganise it into the Organization for Security and Cooperation in Europe (OSCE) from 1995, its role and significance, at least in the Baltic Sea region, was decreasing because this organisation, focused on conflict prevention and management, did not dispose of the necessary means and could not respond to security strengthening needs of the states in the region. Meanwhile, the PfP, though having no intention to replace CSCE or push it out, inevitably became an important framework in which the NATO's stabilising effect became much more strongly perceived than before. It was of vital importance that "Partnership for Peace: Framework Document" clearly stated that "NATO will consult any active participant in the Partnership if the Partner perceives a direct threat to its territorial integrity, political independence, or security"18.

${ }^{17}$ At the informal NATO Defence Ministers meeting on October 20-21, 1993 in Travemunde The US Defence Secretary Les Aspin denied that delays in admitting new members showed deference to the Russian opinion and said "it is not that we are afraid of Russian threats". Les Aspin said that the question of new membership had been considered in the context of the US proposal for series of limited defence arrangements, or "partnership for peace" between NATO and individual eastern European countries. Underlining the merits of this plan which was said to have been unanimously endorsed, Aspin said that it would lay the "military groundwork" for eventual integration of new members into NATO.

${ }^{18}$ NATO, Partnership for Peace: Framework Document issued by the Heads of State and Government participating in the Meeting of the North Atlantic Council, Brussels, January 10, 1994, http:/ /www.nato.int/docu/basictxt/b940110b.htm, 01062002. 
The PfP and Russia's joining it finalised the process of dismantling the old security regime and meant the formation of a new security situation in Central and Eastern Europe. The resolution of Sweden and Finland on joining the PfP was of particular significance for the Baltic Region. Thus, by the end of 1994, the PfP involving all states of the region became another uniting factor along with CSCE. In a sense, one may say that "Partnership for Peace: Framework Document" as if became a document setting out the most important norms and rules of the security regime established in the Baltic Sea region. On the other hand, one may also say that, after the withdrawal of the Russian troops from the Baltic States and Poland was completed at the end of 1994, when the implementation of the PfP started, the Baltic Sea region finally lost its specificity that had been shaped in the years of the Cold War, becoming an integral part of a wider security system. But further evolution of events showed that such conclusion would be a hasty one, because the security system of both the Baltic Sea region and Europe as a whole was still under formation, at least because the normalisation of Baltic-Russian relations was not completed yet. The Cold War between these states that started in 1992 did not end with the withdrawal of the army.

\section{Vicious Circle of Insecurity in 1995-2000}

The year 1995 was, in a sense, a turning point in the development of the Baltic region security system because the main conflict line threatening security in the region acquired a new quality upon the withdrawal of Russian troops from Poland and the Baltic States. The unequivocal resolution of Poland and the three Baltic States to relate their security guarantees with the projected membership of the North Atlantic Organisation was the main reason for disagreement and pressure. Meanwhile, Russia adhered to a provision that the Baltic Sea region was secure enough - no state posed a military threat to any other state; therefore, NATO enlargement was an unnecessary and provocative step that had to be opposed. This was probably the main factor that complicated relations between the Baltic States and Russia after the withdrawal of the Russian Army. Though the global Cold War had ended, the "minor" Cold War that started in 1992 continued in the Baltic Sea region. Therefore, the status of the security atmosphere in the entire region was to depend on further development of security relations between Russia and its former subordinates.

\subsection{Deadlock in the Baltic-Russian Relations}

Until the decision on NATO's enlargement to the Baltic Sea region is adopted, Russia feels obliged to take any measures to ensure that such scenario would not be turned into reality. Two main lines may be identified in this policy. The main line is an attempt to discredit the Baltic States in the eyes of NATO states - as countries not suitable for the membership in the Alliance. The following main measures of this policy could be mentioned:

- demanding that the situation of the Russian-speaking population in Estonia and Latvia be improved, at the same time indicating that the unwillingness, or, to be more exact, inability of these countries to integrate the Russian community in their societies raises doubts over their democratic nature and respect for minority rights; 
- refusing to finally settle the issue of state borders. Russia has signed a state border treaty with Lithuania only (1997). However, up until now (June 2002) the treaty has not been ratified and has not come into effect thus the LithuanianRussian border (Kaliningrad region) is, in essence, a temporary one. The status of Russia's borders with Latvia and Estonia is also temporary though no treaties have been signed as yet. Thus Russia clearly seeks to demonstrate to NATO states that the latter risk to accept countries with undefined borders, thus involving the Alliance into territorial disputes;

using

the problem of military transit to Kaliningrad region via Lithuanian territory. In this case, also, Russia and Lithuania have just a temporary agreement on the conditions of movement via Lithuania's territory of troops withdrawn from Germany; the agreement was reached at the end of 1993. Even upon completion of the withdrawal from Germany, Lithuania could not succeed in agreeing with Russia on new transit conditions; therefore, the old temporary agreement remained in force as a compromise solution. By this, Russia seeks to demonstrate that Lithuania as a state is not capable of resolving military transit issues; therefore, again, the entire Alliance will be mixed up in these problems.

Without any doubt, this list could be continued with more examples, among which "unintentional" violations of the Baltic States' territory or air space should be mentioned; Russia as if seeks to demonstrate that the protection of the borders of these states will burden the Alliance.

Thus, even after the withdrawal of the Russian army, the Baltic-Russian relations did not substantially change or improve because neither party intended to change their totally opposite positions towards security policy. A Finnish analyst Raimo Vayrynen is absolutely right in asserting that

Stalemate is perhaps the best way to describe the current Baltic-Russian relationship; both parties consider the major concessions impossible, while Russia as the bigger power is unwilling, and possibly, unable to use force to break the political logjam ${ }^{19}$.

Of course, this deadlock of Baltic-Russian relations does not mean that the states have ceased communicating. However, their relations have not been fully normalised despite the withdrawal of troops and therefore, give rise to pressures in the entire region ${ }^{20}$.

In essence, a situation has formed where the sides of the conflict cannot and, to tell the truth, are even not interested to make concessions and seek an agreement. A certain "vicious circle of insecurity" has formed in the Baltic Sea region, and the main actors cannot get out of it by their own efforts. Therefore, policy measures

${ }^{19}$ Väyrynen R., "The Security of the Baltic Countries: Cooperation and Defection" in Knudsen O.F., ed., Stability and the Security in the Baltic Sea Region, London: Franc Cass, 1999, p. 205

${ }^{20}$ At the web site of the Estonian Ministry of Foreign Affairs we could find the following estimation, which is valid for Latvian and Lithuanian relations with Russia as well: "A primary factor hindering the pace of developing relations is the incomplete basis of interstate treaties. Lacking are primarily such mutual agreements as an agreement on borders, an agreement on trade and economic co-operation and an agreement on the avoidance of double taxation". See: Estonian Ministry of Foreign Affairs, "Estonia and Russia", http://www.vm.ee/eng/kat_176/1430.html, 01062002. 
pursued by them are focused on influencing international environment and, first of all, pushing NATO in a certain direction rather than on affecting one another. In other words, there has been no substantial change in the situation since 1995 - it has only become clear that this security dilemma may only be resolved in a wider international context, probably upon developing a security regime acceptable to both conflicting sides. However, as decisions of such nature are born very slowly, a situation of uncertainty and waiting has formed in the Baltic Sea region. The parties have found themselves in a certain transitional period the ending date of which could not be stated by anybody.

Thus, upon the dismantling of the legacy of the Cold War, a new security dilemma arose in the Baltic Sea region; a search for alternative solutions for the dilemma became the main issue on the political agenda. According to the nature of the main security problem - in 1995, the region did not differ much from Central Europe because the Czech Republic's Hungary's and Poland's goal to join NATO could be explained by the same motives. Similarly, Russia's evaluation of this aspiration of the Central European countries was negative and Russia openly opposed it. Nevertheless, peculiarity to the situation in the Baltic Sea region was lent by the proximity of Russia and by special posture of Sweden and Finland because these countries chose, this time voluntarily, a security policy strategy different from that of Central European and Baltic States. They, first of all, decided to seek membership in the European Union, not in NATO, and to participate in the formation of the common EU foreign and security policy. While the Baltic States foremost made a bid for NATO but not for the EU membership.

\subsection{Search for Alternative Security Guarantees for the Baltic States}

In spite of the consistent official policy of the Baltic States aimed at continuing NATO pre-accession, there have been numerous proposals, ideas and discussions on how the Baltic security issue and, at the same time, the security regime of the entire region, could be settled alternatively, leaving the Baltic States beyond NATO temporarily or even for ever. Though these discussions did not have any practical impact upon the policies of the Baltic States, they were sufficiently important in the sense that they had to assist both NATO member states and Russia in deciding on further attitudes toward the Baltic States.

Probably the main idea that was widely discussed at that time was the "regionalisation" of the Baltic Sea region's security, creation of a kind of regional security regime with its participants restricted to military non-aligned Baltic and Scandinavian states. For example, in May 1996, Douglas Herd, the former British Secretary of Foreign Affairs, proposed to establish "a Baltic security sub-zone"21 . At first sight the idea seemed quite logical because the Baltic Sea region consisting of small democratic and peaceful countries may easily form a classical regime with common norms, rules and decision-adoption procedures. It seemed clear that norms of cooperative security rather than unilateral attempts to ensure security by military means would easily take root in the region. By the way, this proposal received immediate

${ }^{21}$ Quoted in: Peter van Ham, "The Baltic States and Europe" in Hansen B., Heurlin B., eds., The Baltic States in World Politics, New York: St. Martin's Press, 1998, p. 38. 
support in both Bonn and Moscow. Even Sweden supported it in part. However, the Swedish Prime Minister Goran Persson expressed only a qualified support for the idea during its visit to the USA in August 1996. The Prime Minister stressed that though Sweden would have been the largest participant in this group it did not undertake to act as a guarantee of the Baltic States' security, since the status of Sweden as a non-aligned state did not permit it to assume any military obligations in respect of the Baltic States. Therefore, according to Persson, the governments of the Baltic States know very well that, in order to balance the eventual restoration of Russian imperialism, they need a much greater help than that offered by the northern neighbours.

In the context of the debate concerning the security of the Baltic Sea region, a novel proposal from Ronald Asmus and Robert Nurick, Rand corporation analysts, was met with greatest attention. In the summer of 1996, Asmus and Nurick wrote that the Baltic States would probably not get into NATO with the first wave of candidates and, until the issue of their future NATO membership is decided, the speedy accession of Estonia to the European Union and making its status equal to that of Sweden and Finland would constitute an alternative for the Baltic States membership of NATO. To tell the truth, this proposal was presented only as a temporary answer to the question as to what could be undertaken after the Baltic States will not be invited to the Alliance at the Madrid meeting in July 1997. The authors of the study recognise that:

NATO - and only NATO - can create the overall security framework, which will make it easier for the EU to enlarge to the Baltic States and easier for non-NATO countries to become more involved as well ${ }^{22}$.

Finally, speaking about alternative ways of ensuring security of the Baltic States one should not forget that there were people, both in Russia and the West, who thought that NATO enlargement to the Baltic States was a wrong and irresponsible undertaking. As an illustration we may present reasoning of a Swedish researcher Lena Jonson. While studying Russian policy toward CIS countries she notes a large gap between what Russia declares and what it would like to do in respect of the socalled "Near Abroad". Not in a position to use military force, Russia makes use of the new states, weaknesses and tries to interfere with the internal political processes and exert influence that is beneficial to it. The researcher is of the opinion that this conclusion may also be adapted to the security of the Baltic States. Therefore, the response of the West should be appropriate:

In terms of the Baltic States' vulnerable national security, the eventual threat from Russia would more likely include the use of political pressure rather then military force or threats. Subsequently, the West answers to this challenge would be help to minimize all economic and political vulnerabilities of the Baltic States in relations to Russia $^{23}$.

A logical conclusion, made on the basis of Jonson's and other similar reaso-

\footnotetext{
${ }^{22}$ See: Asmus R., Nurick R., "NATO Enlargement and the Baltic States”, Survival, Summer 1996, vol. 38 , no. 2 , pp. 139.

${ }^{23}$ Jonson L., "Russia and the "Near Abroad" in Hansen B., Heurlin B., eds., The Baltic States in World Politics, New York: St. Martin's Press, 1998, p. 128.
} 
ning, would be that not NATO enlargement but the Baltic States' accession to the EU would be an adequate measure to resolve the issue of the security of the Baltic Sea region, since membership of the EU would provide the most important security guarantee - smooth socio-economic development of the States, restricting Russia's possibilities for directing these processes in a way favourable to Russia.

\subsection{First Wave of NATO Enlargement and Russia's Security Guarantees}

During the NATO summit meeting in Madrid in 1997, a piece of news that was not very joyful for the Baltic States was announced that is that consideration of their applications for NATO accession was to be postponed for an indefinite future. Only the Czech Republic, Hungary and Poland were invited to start accession negotiations in July 1997. However, the Madrid meeting stressed - which was very important for the futurethat NATO enlargement was a process which did not end with this stage of admission and that NATO would continue to pursue its policy of "open doors" based on Article 10 of the North Atlantic Treaty. Therefore, the Baltic States had to console themselves with the following recognition of their efforts contained in a single sentence:

At the same time, we recognise the progress achieved towards greater stability and cooperation by the states in the Baltic region which are also aspiring members ${ }^{24}$.

However, there were probably two factors important for the security situation of the Baltic Sea region and its further development. First of all, the State which both belonged to Central Europe and was important for the region - Poland - was invited to NATO. The Polish-Lithuanian border became the first border of the Baltic States with a NATO country. This gave a certain hope for the future that NATO's enlargement will be continued.

Another fact that seemed very important for the Baltic region occurred before the publishing of the Madrid declaration. This was Founding Act on Mutual Relations, Cooperation and Security between NATO and the Russian Federation signed in Paris on 27 May $1997^{25}$. The Act confirmed once again that NATO and Russia did not consider each other as adversaries. Under the Act the Permanent Joint Council (PCJ) was founded as a forum of consultations and joint decisions in case of agreement by the parties. The document also identified problems on which consultations between NATO and Russia could be held: prevention of conflicts, distribution of mass destruction weapons, exchange of information on security and defence matters, conversion of defence industries, environmental protection, civil safety etc. It was stated in the Act that, upon signing the document, NATO did not become subordinate to any other organisation or state and that it did not intend to modify its obligations to present and future NATO members in the security area. The Act contained no

\footnotetext{
${ }^{24}$ NATO Summit. Madrid, July 8-9, 1997, Madrid Declaration on Euro-Atlantic Security and Cooperation, http://www.nato.int/docu/pr/1997/p97-081e.htm, 01062002.

${ }_{25}^{5}$ NATO - Russian Summit, Founding Act on Mutual Relations, Cooperation and Security between NATO and the Russian Federation, May 27, 1997, http://www.nato.int/docu/basictxt/fndact-a.htm, 01062002 .
} 
guarantees for Russia concerning the stopping of NATO's enlargement.

Such document regulating NATO-Russian relations was undoubtedly a new phenomenon in security environment; it demonstrated, for the first time, that there existed certain principles, norms and rules that could be subscribed to even by the former Cold War antagonists. This was a step forward in comparison with a quite limited agreement between NATO and Russia within the framework of PfP. However, on the other hand, it was obvious that the document as though lacked a certain link which would unite the two forces that still seemed opposing rather than collaborating. This was perhaps owing to the fact that each side viewed the importance of the Act differently and had different expectations. By forming a Permanent Joint Council, NATO member states expected to mitigate Russia's negative reaction after the forthcoming announcement in July that Poland, the Czech Republic and Hungary will be admitted to NATO after two years. Meanwhile, Russia probably expected that it would have greater influence over NATO's decisions and would be able to stop further enlargement, first of all, to the Baltic Sea region, after the accession of the above-mentioned countries. Tending to treat the signing of the Act and NATO's decision on limited enlargement as Russia's victory, Russia now evidently decided that it was high time to take over the initiative and to start pursuing a more active policy in the Baltic Sea region. The most obvious manifestation of such modified Russian policy, a kind of détente, was Russia's decision to sign a state border treaty with Lithuania in 1997 and, within this framework, offer Lithuania and other Baltic States to enter into a treaty on security guarantees.

Speaking at the UN General Assembly o 22 September 1997, Yevgeny Primakov, Russian Foreign Minister (who had replaced Andrey Kozyrev in 1996), officially stated that Russia was interested in the stability of the Baltic States and wished to ensure their security. According to Primakov, Russia could undertake to guarantee their security upon signing agreements on good neighbourhood relations. In the opinion of the minister, such agreements could develop into a regional security pact. Algirdas Brazauskas, President of Lithuania, heard the same statement during his official visit to Moscow in October. Yeltsin guaranteed that no unexpected things were awaiting Lithuania on the part of Moscow. As one could forecast, Lithuania and other Baltic States rejected Russia's initiative. It was stated in a document published by the Ministry of Foreign Affairs of the Republic of Lithuania that "neither unilateral security guarantees legalised in the form of a treaty nor regional security pacts can safeguard the security of Europe, including Lithuania. In the opinion of Lithuania, the security and stability space in Europe will be extended by the Baltic States' integration in the European Union and NATO"26.

Why a proposal, so attractive from the first glance, was rejected? One can hardly find an explanation better than that provided by Zbigniew Brzezinsky, as early as 1991, in his book "The Grand Chessboard":

...the Russian Democrats simply could not grasp the depth either of the Central European's resentment over half a century of Moscow domination or of their desire to

${ }^{26}$ ELTA, "Russian guarantees cannot safeguard security for Lithuania", October 30, 1997. - in Lithuanian.

${ }^{27}$ Brzezinsky Z., The Grand Chessboard. American Primacy and Its Geostrategic Imperatives, New York: Basic Books, 1997, p. 102. 
be part of a larger Euro-Atlantic system ${ }^{27}$.

Thus the détente in Russian-Baltic relations was quite short. No further progress took place in these relations. Finally, the Permanent Joint Council of NATO and Russia appeared to be completely ineffective; its work was finally stopped due to Russia's protest against NATO's actions aimed at resolving the Kosovo crisis by military force.

\subsection{Temporary "Settlement" of the Baltic Issue}

After NATO made known its decision to enlarge, a new situation started forming in Europe, with new contours of security architecture, where a place could be found for the Baltic States. Therefore, though it seems paradoxical, namely the Baltic States could adapt their policy to the changing situations most easily. Nothing had to be changed substantially - only the work started within the PfP and EAPC framework had to be continued. Having not received an invitation to NATO, the Baltic States had to satisfy themselves with, and successfully made use of their status of countries almost universally recognised as NATO candidate countries. They understood that NATO faced serious difficulties in including them in the first round of the enlargement. But the first successful enlargement formed a solid basis for the final settlement of the region's security problems in the way desired by the Baltic States.

All the Baltic States after the "first rejection" were trying to substantiate their membership credentials by participating as fully as possible within the PfP, trying to demonstrate that they were not only "consumers" of security, but were and would be, a valuable asset for the Alliance as a whole. Baltic participation in Bosnia Implementation Force (IFOR) was therefore symbolically very important. In Bosnia, Baltic forces worked together with Swedish, Finnish and Polish contingents in a Nordic Brigade, operating side by side with Russian troops, all under the US command and under NATO auspices. The Baltic Sates also often participated in PfP annual exercises like the Baltic Challenge. All three countries also participated in the PfP Planning and Review Process, which was designed to advance interoperability and increase transparency among Allies and partner countries. The desire to strengthen ties with NATO in order to ultimately join the Alliance, had already positively influenced cooperation among the Baltic States in security and defence fields (BaltBat), and had also speeded up internal defence policy reviews.

Meanwhile the USA, with regard to the urgency of the Baltic problem and seeking to demonstrate that the door to NATO remained open, initiated the US Baltic Charter of Partnership, which was signed in January 1998. The primary importance of this document for the Baltic States and their security was related to the fact that, probably for the first time on the highest political level, it was confirmed by the signature of the US President that their wish to join NATO was treated sufficiently seriously. While the Baltic Charter did not specifically provide a US guarantee of Baltic security or NATO membership, it declared that the ultimate goal of the signa-

${ }^{28}$ A Charter of Partnership Among the United States of America and the Republic of Estonia, Republic of Latvia, and Republic of Lithuania, Washington, DC, January 16, 1998, http:// www.usemb.se/BalticSec/baltic_charter.html, 01062002. 
tories was to incorporate the Baltics into European and transatlantic political, economic, security, and defence institutions ${ }^{28}$. Although the Baltic Charter did not specifically guarantee that the Baltic republics would become members of NATO, the US Administration statements left little doubt that the United States was committed to helping create conditions for the Baltic membership within NATO's ongoing enlargement process. The administration support for the Baltic membership in NATO was confirmed during the Baltic Charter signing ceremony when President Clinton declared, "America is determined to create conditions under which Estonia, Lithuania, and Latvia can one day walk through the [NATO's] door."

The period 1995-2000 was the years when debates took place and preparations were made for the decision on which of the two Baltic Sea regional security scenarios was more suitable and, therefore, worth greater political support. One of the basic scenarios proposed, which, despite its attractiveness, seemed unreal enough, was NATO's consistent development and final involvement of the Baltic region in the Euro-Atlantic security zone. As an alternative, the idea of "regionalisation" of the Baltic Sea region security was advanced in one form or another. The debate particularly intensified when a decision not to include the Baltic States in the first wave of the enlargement was adopted. However, this specific security regime based on a special regional agreement or a regional security pact appeared to be unacceptable to the Baltic Sea states except Russia. In this context one may also mention debates initiated by the European Union and certain actions aimed at forming the European Security and Defence Policy (ESDP). To tell the truth, the title of this initiative is slightly misleading because it has nothing to do with defence and cannot constitute an alternative to NATO, which is a collective defence organization and plays a leadering role in crisis management. The ESDP applies only to the so-called "Petersberg tasks". Nevertheless, the Baltic States supported the EU's Headline Goal for 2003 (Catalogue of Forces), but their contributions are the same as those they pledge for NATO operations.

Thus no turning point in defining the security architecture in the Baltic Sea region occurred in the period concerned. A situation of uncertainty was preserved. On the one hand, the Baltic States were never told that they would not be admitted to NATO in the future. On the contrary, they became as if official candidate countries for the accession to the Alliance. The evolution of NATO's strategic concept recorded in the NATO summit meeting in Washington was of particular importance in this respect. On the other hand, the prospects of NATO membership of these countries nonetheless remained quite vague because NATO-Russian relations were sharpened by dynamic changes in the international situation, ineffectiveness of the NATORussian Permanent Joint Council, and Kosovo crisis; therefore, speedy and wide development of NATO, where the Baltic States could probably find a place, became quite doubtful. Anyway, the NATO-Russian agreement of 1997 was particularly important for the developing Baltic Sea region, at least formally. The very fact of NATO-Russian attempts to create a new regime of mutual relations was significant. It was only a lack of political will that impeded the use of the infrastructure built. However, as it appeared later, situations may sometimes form when political will 
changes quite quickly.

\section{2001: the Lacking Link Found?}

In 1999-2000, the discussion over the European security architecture and NATO enlargement as if quieted down because it became clear that it was not yet time for principal decisions. Changes in power had matured in the two most important states of the process, the USA and Russia. The second term of office of the US President Bill Clinton was nearing its completion and a pre-election campaign started. Meanwhile, Russia was struck by a replacement of leadership initiated by President Yeltsin, the war in Chechnya was renewed in 1999, finally, Yeltsin himself announced about his resignation on the eve of 2000 - as always, unexpectedly. Therefore, the presidential election had to take place in Russia in March 2000.

However, it did not seem that positive developments were expected in the international situation after the completion of changes in the governments of the USA and Russia. On the contrary, it sometimes appeared that the new Russian President, Vladimir Putin, tended to make its opposing position towards the West stricter and even attempted to form a bloc of states hostile to the USA. The new Russian President visited China, North Korea, Cuba and even Libya. Authoritative trends apparently strengthened within Russia. Meanwhile, when George W. Bush after a complicated vote recounting procedure was elected President and took over the direction of the US foreign policy, contradictions between the USA and its allies in Western Europe as if became sharper. The governments of the largest West European states were quite sceptical in respect of the US initiative to start creating a national anti-missile defence system and of statements concerning the USA's potential withdrawal from the Balkans.

In this context the issue of the future of NATO's enlargement had as if retreated to the background. Since it was only in November 2002 that principal decisions were expected, such uncertain situation gave birth to various enlargement scenarios and speculations. Some believed that even if NATO was going to enlarge in this situation of uncertain relations with Russia and disagreement with West Europe, the enlargement would be very limited - only Slovenia and Slovakia would be admitted from the important defence and strategic points of view. With regard to the Baltic States, the commentators were particularly cautious. Even such alternatives as the repetition of the scenario selected by the EU in 1997 were seriously considered. As it is known, the EU then decided to invite only one Baltic state, Estonia for negotiations. Now such experience could be adapted for NATO's enlargement by inviting Slovenia, Slovakia, one of the Baltic States - Lithuania, because of its relatively small Russian minority and geographical contiguity with NATO. In such a case one could expect that Russia would not be antagonised completely, at the same time showing it that NATO was moving forward, slowly, but in a planned way ${ }^{29}$.

However, all these speculations as if lost their basis after the new US administration publicly expressed its position on NATO enlargement for the first time. The Baltic States and all other states willing to join NATO heard good news from Presi-

${ }^{29}$ Gordon P., Steinberg J.B., "NATO Enlargement: Moving Forward; Expanding the Alliance and Completing Europe's Integration", The Brookings Institution Policy Brief, $n$. 90, November 2001, http://www.brook.edu/comm/policybriefs/pb90.htm, 01062002. 
dent Bush in June 2001 during his visit to Poland. At his meeting with teachers and students of the Warsaw University the President said:

I believe in NATO membership for all of Europe's democracies that seek it and are ready to share the responsibilities that NATO brings. The question of "when" may still be up for debate within NATO; the question of "whether" should not be. As we plan to enlarge NATO, no nation should be used as a pawn in the agendas of others. We will not trade away the fate of free European peoples. No more Munichs. No more Yaltas. Let us tell all those who have struggled to build democracy and free markets what we have told the Poles: from now on, what you build, you keep. No one can take away your freedom or your country.

Next year, NATO's leaders will meet in Prague. The United States will be prepared to make concrete, historic decisions with its allies to advance NATO enlargement. Poland and America share a vision. As we plan the Prague Summit, we should not calculate how little we can get away with, but how much we can do to advance the cause of freedom.

The expansion of NATO has fulfilled NATO's promise. And that promise now leads eastward and southward, northward and onward ${ }^{30}$.

One can see that the statement was sufficiently clear and strict; but, at that time, few noticed that Russia's reaction to this statement was reserved and calm as never before. Later in the summer, Putin took a further step toward acknowledging the inevitability of the enlargement by expressing the view that Russia might itself want to join NATO, as an alternative to his preferred option of seeing NATO disappear. As it appeared later it was not an accident but a manifestation of the first changes in Russian foreign policy. There were also other signs of these changes. Already from the very start of 2000, albeit giving mixed signals regarding Russia's pro-Western orientation, the newly elected President Putin paved the way for a more constructive co-operation. As a result, already in May 2000, the NATO-Russia Permanent Joint Council (PJC) resumed its work, which was ceased in protest over NATO's air campaign against Serbia, and further on gradually expanded its agenda. It was followed by the opening of NATO's information office in Moscow in February 2001. Nevertheless, the turning point took place on 11 September 2001. Putin's position in respect of the dreadful terrorist acts in New York, expressed clearly and unequivocally, testified to the fact that finally a basis for the US-Russian rapprochement appeared. In other words, the missing link - "the common enemy" - that both sides wished and had to fight - was found.

The consequences of these changes for the Baltic Sea region were, perhaps, best characterised by the British weekly "Economist", which presented overviews of the latest developments in the Russian-NATO relations, particularly having regard for the projected NATO enlargement and possible Baltic States' membership of the Alliance, which, according to the magazine, had seemed impossible five years ago. Now the Baltic States may expect an invitation to NATO because Russia, after such radical changes on the international politics stage and emergence of new threats, ceases being intractable and sees no sense in fierce opposition to the admission of the Baltic States; Russia can even afford to say that NATO enlargement is no longer

\footnotetext{
${ }^{30}$ Bush G.W., Remarks by the President in Address to Faculty and Students of Warsaw University, http://www.whitehouse.gov/news/releases/2001/06/20010615-1.html, 01062002.
} 
relevant to Russia's security. Even more, Putin is now in a position to explain to the domestic opposition and the Russian hard-liners that NATO is losing its military importance because the organisation is not very useful in fighting terrorism, as shown by the military campaign in Afghanistan - the USA adopts the most important decisions unilaterally and selects partners for specific operations at its own discretion ${ }^{31}$.

Thus at the beginning of 2002 it became clear that the issue of NATO's enlargement to the Baltic Sea region was in substance resolved. However, the final shape of the region's security regime depended on specific legal and institutional results to be brought by the rapprochement between Russia and NATO. This was cleared up in Reykjavik in May 2002 where a meeting of NATO's and Russia's foreign ministers was held. An agreement on a closer cooperation between NATO and Russia was finalised in Reykjavik. The document entitled "NATO-Russia Relations: A New Quality"32 formally establishing the NATO-Russia Council was signed in Rome on 28 May 2002 during the NATO-Russia summit meeting.

Formally and officially, the document should facilitate and strengthen fighting against the main threat of the $21^{\text {st }}$ century - international terrorism. The main difference between this document and the NATO-Russia Founding Act of 1997 lies in the clause under which Russia will participate in the adoption of NATO's decisions. Up until now NATO states first adopted a decision and then acquainted Russia with it. This has been the main cause of Russia's dissatisfaction. Now Russia is going to be involved in consultations. For this purpose a new council headed by the Secretary General is being formed. However, not all security issues will be covered by the council. The council, just as the Act of 1997, will be a place for agreeing on the cooperation in fighting international terrorism, on disarmament and joint aid in case of natural disasters. The activities of the council will help form a common attitude toward the prevention of distribution of mass destruction weapons, joint work aimed at developing the anti-missile defence system, performing of peacemaking operations etc. However, at the same time the document does not provide for Russia the veto right in resolving issues related to NATO's enlargement ${ }^{33}$. In addition, NATO does not refuse one of the central provisions of the North Atlantic Treaty, which states that an attack against any country of the Alliance means an attack against the Alliance as a whole. Therefore, in such a case NATO will not be obliged to ask Russia's permission to fight the aggressor.

Of course, today it is difficult to say how this new NATO-Russia Council will act and whether it will not experience the fate of the previous Permanent Joint Council. According to the commentators from "Radio Liberty", the format of the latter council also provided conditions for cooperation; however, problems arose because Russia did not show any will for such cooperation. Now, with Russia having equal

\footnotetext{
31 "Putin's unscrambled eggs: Russia, NATO and even the Baltic states may end up friends", Economist, March 9, 2002.

${ }^{32}$ Rome Summit - 28 May 2002, NATO-Russia Relations: A New Quality. Declaration by Heads of State and Government of NATO Member States and the Russian Federation, http://www.nato.int/ docu/basictxt/b020528e.htm, 19102002.

${ }^{33}$ Fact Sheet "NATO-Russia Council", http://www.whitehouse.gov/news/releases/2002/05/200205283.html, 01062002.

${ }^{34}$ Radio Liberty, "New relations between NATO and Russia”, http://www.svoboda.org/archive/ 1l_world/0502/11.051602-1.asp, 01062002 - in Russian.
} 
rights with NATO's members in resolving the issues of the Rome Declaration, there are grounds for expecting such political will to exist. ${ }^{34}$

If the NATO-Russia Council will be an effective one, one may expect that the states of the Baltic Sea region should become members of the Council upon joining NATO. Therefore, their security relations with Russia should acquire a new quality, which could be called the embodiment of the new security regime in the region. Anyway, the main parties to the conflict line in the Baltic Sea region-Russia and the Baltic States - would be finally placed in a wider international context, which, in its turn, would provide conditions for final normalisation of their relations and enable to end this "minor" Cold War.

\section{Conclusions}

To summarise the results of the study, the development in the security regime of the Baltic Sea region could be shown in this simplified table format:

\begin{tabular}{|c|c|c|}
\hline Period & Main Challenges & $\begin{array}{l}\text { International legal acts containing } \\
\text { principles, norms and rules } \\
\text { important for the region's security }\end{array}$ \\
\hline before 1991 & $\begin{array}{ll} & \text { Cold War } \\
- & \text { Nordic Balance }\end{array}$ & $\begin{array}{ll}\text { - } & \text { UN Charter, } \\
\text { - } & \text { Finnish - Soviet FCMA Treaty } \\
\text { - } & \text { CSCE: Helsinki Final Act }\end{array}$ \\
\hline $1991-1994$ & $\begin{array}{l}\text { - } \\
\text { - } \quad \text { Wismantling of the old regime } \\
\text { the Baltic States }\end{array}$ & $\begin{array}{ll} & \text { CSCE: Paris Charter for New } \\
\text { Europe } \\
\text { - } & \text { NACC } \\
\text { - } & \text { PfP Invitation and Framework } \\
& \text { Document }\end{array}$ \\
\hline $1995-2001$ & $\begin{array}{l}\text { - Miniature Cold War between Russia } \\
\text { and the Baltic States } \\
\text { - } \quad \text { First NATO enlargement } \\
\text { - Search for alternative solutions of the } \\
\text { Baltic States' security problems and } \\
\text { rejection of the security } \\
\text { "regionalisation" alternative }\end{array}$ & $\begin{array}{ll}\text { - } & \text { EAPC / Enhanced PfP programme } \\
\text { - } & \text { NATO - Russia Founding Act } \\
\text { - } & \text { US - Baltic Charter }\end{array}$ \\
\hline since 2002 & $\begin{array}{l}\text { Fighting terrorism as new grounds } \\
\text { for NATO-Russia rapprochement } \\
\text { Admission of the Baltic States to } \\
\text { NATO }\end{array}$ & $\begin{array}{l}\text { - } \\
\text { Rome Declaration "NATO-Russia } \\
\text { - } \quad \text { North Atlantic Treaty and the } \\
\text { Alliance's Strategic Concept }\end{array}$ \\
\hline
\end{tabular}

\section{Changing security regime in the Baltic Sea region}

Both the entire study and the table presented clearly show that the institutions limited to the Baltic States themselves and even the European Union are practically significant only as facilitators for the so-called "soft" security issues, which have nothing in common with defence. The attempts to raise the issues of the security of Estonia, Latvia and Lithuania at the Council of the Baltic Sea States as well as the idea of the regional security pact were rejected at once and without any wider discussion as not adequate to the scope of the problem. Though the Baltic Sea region appears to be an ideal place for the formation of a classical regional security regime with common norms, rules and decision-adoption procedures, this assumption appears to be sub- 
stantially wrong for one simple reason - Russia, though today it is not the Soviet Union already, cannot accommodate itself in this regional format.

The regional security regime in the Baltic Sea region, with all the rim states (and Russia) included, could not successfully exist due to the obvious dominance of Russia. However, the regime itself could not exist without Russia because the main conflict line and the greatest security challenge in the region are related to this country. Therefore, only international institutions of a wider scope are capable of resolving the dilemma of the Baltic security and performing the conflict prevention function.

We could see that CSCE had successfully coped with this task in 1991-1994. CSCE was the international format that ensured successful withdrawal of Russian troops from the Baltic States. However, it soon became clear that the organisation is of little use in further settlement and normalisation of the Baltic-Russian relations. As it is known the conflict acquired another shape upon the withdrawal of the Russian army: a miniature Cold War between the Baltic States and Russia started, with its periods of sharpening of conflict and détente. Meanwhile, CSCE could undertake practically nothing to contribute to the ending of this war. In the best case, it could preserve the status quo but could not act as a sufficient factor helping to settle security problems. Therefore the regional Cold War could only be ended by the influence of international institutions capable to conduct an equal dialogue with Russia. And NATO could become such institution. After uniting its former antagonists into NACC, then into EAPC and the PfP, it managed to find a peculiar form of institutionalisation of relations with Russia - the Permanent Joint Council, which begun its activities with the decision to start enlarging the Alliance by admitting three states of Central Europe. Thus, the stabilising role of NATO was strengthening and it was increasingly present in the region. However, one must state that even this role was not an adequate factor that could determine the final normalisation of the Baltic-Russian relations. Therefore, the security regime that existed in the Baltic Sea region almost up to 2002 can be characterised as a preserved situation of uncertainty, the resolution of which was constantly postponed for the future.

Finally, in November 2002 when the last lines of this study are written, it appears that after long hesitations and preparations NATO has at last decided on admitting the Baltic States to its ranks. Therefore, one may say that the formation of the security regime in the Baltic Sea region is getting a new quality level. It will become a more NATO-centric regime than before because even countries formally not members of NATO will have established solid relations with this organisation. This applies to Finland and Sweden for a long time already. There is a chance now that the same will soon apply to Russia whose partnership relations with NATO were established in the Rome Declaration of 28 May 2002. Thus, in the future, the Baltic Sea region's security regime could transform into a structure supported by two main pillars and embrace all the actors in the region:

- the states of the Baltic Sea region - NATO members - Germany, Denmark, Poland, Lithuania, Latvia and Estonia;

- the states of the Baltic Sea region - NATO partners - Sweden, Finland and Russia.

Of course, for the time being it is not clear how the structure will work, and if it will work at all. We will see this from the development of relations between Russia and the Baltic States, however, today it seems that all preconditions exist for ensuring security and stability without ignoring or leaving anybody overboard. 